\title{
The College Librarian: Sociology of a Professional Specialization
}

Mrs. Knapp is librarian, George Williams College, Chicago.

$\mathrm{E}^{\mathrm{v}}$ VERY JOB IS MORE than a set of tasks or functions. It is a set of relationships as well-relations with authority, relations with others in the same trade or profession, relations with fellow-workers on the job, relations with clients or customers. Specialization within a field, moreover, often involves special relations as well as special functions.

The college librarian's job is obviously a specialization of this sort. Not only his functions but also his relationships are, in large measure, determined by the institution he serves.

This paper, therefore, considers in some detail the pattern of relationships which affect college librarianship as a professional specialization, particularly those which are inherent in the college as a social institution.

\section{The College}

The college is a complex institution. It is comparable to the hospital in many respects. And in sociological studies of the hospital $^{1}$ one can find parallels which are pertinent to the present analysis. In the hospital, as in the college, complexity of organization reflects a wide variety of functions performed, structuring, to some ex-

\footnotetext{
1 Smith, Harvey L. "The Sociological Study of Hospitals." (Unpublished Ph.D. dissertation, University of Chicago, 1949).
}

tent, the relationships among three major groups: the administrators, the professionals, and the clients.

As in the hospital the key relationship is that between doctor and patient, the key relationship in the college is between teacher and student. Since the main business of the college is education, highest value is placed on this relationship. The administration exists to facilitate it.

A problem of the college, as of the hospital, however, lies in the fact that two status systems exist simultaneously within it, the one bureaucratic, reflecting the administrative hierarchy, the other functional, reflecting the values placed by the community on the functions performed. The conflicts arising out of this dichotomy are probably not as critical in the college as they are in the hospital, but they exist nonetheless.

Within this general pattern of relationship, the librarian is responsible for an enterprise which is ancillary to the main business of the institution, comparable, perhaps, to the pharmacy department, the pathology department, the nursing department in the hospital. Such enterprises are essential to the achievement of the purpose of the parent institution, but they are subordinate, and the position of those responsible for them is often anomalous.

\section{The Librarian's Functions}

The functions of the head librarian of a college fall into three categories. First, as 
the administrator of an auxiliary enterprise, he is often responsible for the expenditure of large sums of money, the maintenance of extensive plant and equipment, the organizing and servicing of a tremendous investment in material, and the supervision of a large staff. Second, because the library is designed to implement directly the educational process, he is, in a sense, an educator. His work is much closer to the teacher-student relationship than is that of the comptroller or the engineer, for example. And finally, because he works with books, he is a bookman, even, perhaps, a scholar.

All of these functions are clearly important. The degree of emphasis placed upon any one of them varies in a given situation with the nature of the institution and with the taste and talent of the librarian. We are concerned here not with the usual or proper dominance of any one of the functions, but with the pattern of relationships around each.

As an administrator, he must work frequently and closely with people in the personnel department, the purchasing department, the buildings and grounds department, etc. He values orderly procedures, smoothness of operation. His attention is focused on economy and efficiency.

As an educator he must work closely with the teaching faculty. He values service keyed to instructional goals. His attention is centered on curriculum-building, teaching methods, student use of the library.

As a bookman he works closely with the scholars and research men on the faculty. He values the good collection, the research materials, perhaps the rare books. His attention is centered on research needs, bibliographical tools and services.

All of these relationships are inherent to one degree or another in his job. In addition, as a librarian, he is influenced in some measure by the notions which are attached to the library itself, particularly to the public library. He values reading as a good in itself. He values skill in the use of the library as a tool for self-education. He feels an obligation to promote use of the library quite apart from its relationship to instructional objectives.

It is worth repeating that any one college librarian may stress one or another of these elements in his concept of his own in the college. But all of the elements are present. They are, furthermore, all present in the composite faculty concept of the librarian's role, as we shall see.

\section{The Librarian's Status}

How, then, do these various functions and the relationships they involve affect the status of the librarian in the college community? In a situation where the instructor ranks high and the administrator ranks low on the functional status scale, the status of the librarian may be determined by which function is stressed in his work, in his self-concept and in the concept of him held by others in the college community.

In the academic community, faculty rank is an important and convenient symbol of status. Indeed, faculty rank is a prize for which academic librarians are still fighting. ${ }^{2}$ The head librarian is accepted as a member of the faculty in most colleges. But he is not always so accepted, nor is his position always clear. The catalogs of five highlyregarded colleges in the Midwest listed the librarians as follows:

\section{College A .... Librarian and Professor of Library Science \\ College B .... (with administrators, not with faculty) \\ College C .... Librarian (under rubric As- sociate Professor)}

2 Downs, Robert B., "Are College and University Li brarians Academic?" COLLEGE AND RESEARCH LIBRARIES, I 5 :9-I 4, January, I 954. 
College D ... Librarian with Rank of Assistant Professor

College E .... Librarian and Associate Professor of English

Only in College A were other members of the library staff listed as faculty. Here, these others have teaching responsibility in the Department of Library Science.

In one of these colleges, the writer interviewed twenty-nine faculty members, in connection with another study. Twentytwo of them were asked if the librarian should be a member of the faculty. Seventeen answered "yes" unequivocally. The other five had reservations, not about the incumbent librarian, but about the librarian in general. They were then asked if they thought the rest of the professional library staff should also have faculty rank. They answered as follows:

$$
\begin{array}{rll}
12 & \ldots & \text { no } \\
2 & \ldots & \text { yes } \\
2 & \ldots & \text { depends on function } \\
2 & \ldots & \text { depends on training } \\
I & \ldots . & \text { depends on person }
\end{array}
$$

They were not asked their reasons for their opinions but some volunteered it. The reasons given reveal pretty clearly one or another of the following attitudes toward faculty rank:

I. Faculty rank as a status symbol:

"They are not intellectual."

"I hate the dichotomy between faculty and staff."

"They are adequately represented by the librarian."

"I feel there can be proliferation of faculty rank."

2. Faculty rank as related to function:

"They have no contact with educational matters where policy is required."

"They are concerned with instruction and discipline."

"The reference and circulation librarians are concerned with the educational program."
3. Faculty rank as related to training:

"They should have equal rank for equal training."

These quotations demonstrate that faculty rank is recognized as a status symbol, and that where it is jealously guarded, the librarian is considered to be qualified for it primarily by virtue of his function as educator or scholar.

It should be pointed out that in this particular college, the librarian is a member of the faculty, held in high esteem by his colleagues. He has an advanced degree in history, has taught English in the college, and he is clearly a bookman in his interests. $\mathrm{He}$ is also considered a good administrator, and his committee work in the faculty has been primarily with administrative committees.

To get a further idea of the faculty member's conception of the role of the librarian, the respondents were asked to what committees the college librarian, not the librarian of this college but any college librarian, should be assigned. The following committees were named:

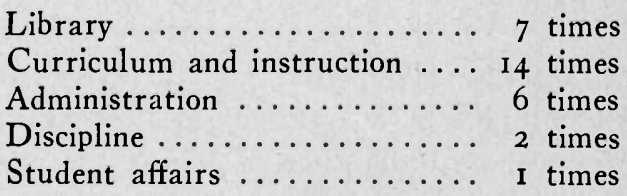

It can be assumed that more respondents would have indicated the library committee had they not felt it obvious. Those who did suggest it invariably commented that it was obvious. Well over half of the respondents apparently think the librarian's function as educator is most important.

They were asked, further, what they conferred with their own librarian about. And they answered as follows:

Books (purchases, search for o.p.'s, etc.) II

Course needs (duplicates, physical setup, etc.) $\ldots \ldots \ldots \ldots \ldots \ldots \ldots \ldots, 4$ 
What use students are making of the

library .................. 2

Other (noise, departmentalization, etc.) 6

From these answers it seems that the bookman function is most appreciated in their own librarian.

To summarize, then, here is a college librarian who is fully accepted by the teaching faculty as one of them. $\mathrm{He}$ is especially valued as a scholar and a bookman. His staff, however, is not so accepted. It is not assumed that they, as librarians, will be either educators or bookmen. One more quotation will emphasize this point:

Q: Should the librarian be a member of the faculty?

A: Not necessarily. Mr. Mhould be. He thinks of other things besides what's going on in the catalog room. He's widely read. He keeps up the quality of the library. He has taught classes.

I might as well say this, too. I know you're studying library science, but I think a librarian should have minimum training in library science and lots of humanities and social sciences, especially humanities. He should recognize content. Mr.

can compete with the faculty on their own terms.

Q: What about the rest of the staff? Should they be on the faculty?

A: No. They are librarians, not intellectual people.

$\mathrm{Q}$ : Are you saying that the head librarian should be given faculty status only if he happens to be a person like Mr.

or that the college should hire only a person like $\mathrm{Mr}$. as librarian?

A: He's the kind of person you should have for a college like this. It should be a requirement that the librarian be able to read, talk, think-for a college like this. I wouldn't be sure of the librarian of Widener, whether he's this kind.

If we are defensive, we will label this comment extreme or even ignorant, but it is honest, and it illustrates the status problem of the college librarian.
It may be helpful to recall here the parallel with the hospital. As an administrator, the college librarian like the pathologist, the pharmacist, the head nurse, may rank high in the administrative hierarchy but low in the functional status system. If he is not accorded faculty rank he may feel that he is not truly a member of the academic profession and, like the pharmacist and the nurse, seek self-esteem within his own occupational specialization. Even with faculty rank, unless he actually teaches, he is likely to feel, as do the pathologist and the anaesthesiologist, ${ }^{3}$ that he does not quite belong, until and unless he proves himself to be personally qualified as an educator and a scholar.

\section{The Librarian's Clients}

Whether or not the instructor is a colleague, he is certainly a client, and this relationship is not without its points of tension. Most college faculty members are interested in research, and they are certainly under considerable pressure to do research. ${ }^{4}$ They are naturally pleased when their own college library is able to provide the necessary materials. But many college libraries do not consider this one of their functions, and, in any case, only a few colleges can afford it even on a limited scale and in limited areas. The provision of research materials and even of services, through microfilm and interlibrary loan, may cause a drain on funds and staff serious enough to hamper the provision of instructional materials and services. Here the librarian faces the conflict of interest between research and instruction.

The allocation of funds for the purchase of books among the various departments

3 Lortie, Dan C. "Doctors without Patients: the Anaesthesiologists." (Unpublished Master's thesis, Uni-

versity of Chicago, 1949.) Wilson, Logan. The Academic Man.
Oxford University Press, I942, chapter II. 
may be another source of friction, for there is rarely enough money to go around. Here the librarian can hope for a generous unallocated, or general, fund so that he can provide for unanticipated needs and adjust to the publication market. Only thus can he keep everybody fairly satisfied.

The faculty client may also cause the librarian trouble with the student client. When an instructor assigns students to books without checking to see that they are in the library, when he is tardy in sending in reserve lists, when he assigns a large class an exercise requiring use of a single reference book or periodical without giving the library adequate warning, he makes the library appear to be inefficient and perhaps ungracious to the student. Many students already consider the library a red-tape outfit, controlled by an ogre and characterized by such unpleasant things as fines and incomprehensible catalogs and "silence" signs.

The relationship of the librarian with his student clientele suffers from these bureaucratic characteristics, some of them necessary, some unnecessary, some exaggerated by faculty carelessness. Furthermore, the relationship which the librarian would like to develop with the student may be in conflict with the instructor's objectives. The librarian is eager to help the student use the library. He wants the student to develop the habit of feeling free to ask for assistance. The instructor, on the other hand, often is afraid that the librarian will do the student's work for him. Sometimes he specifically prohibits the student from seeking help with specific assignments. This is not a usual problem, but it may be symptomatic of the distance between the librarian and the educational process.

The third group with which the librarian must deal, the administrative staff, is not really a client group. In this relationship tensions sometimes develop which are comparable to those between the administrative departments and other academic departments, where educational objectives are in conflict with the smooth, economical and efficient running of the administrative machinery. The librarian necessarily has more points of contact with the administration than do the other academic departments, but because of his own administrative functions he may be better able to understand administrative values and administrative problems. The librarian is usually, however, directly responsible to the instructional head of the college. He must work with the business offices. If there is conflict between the two, he may find himself in the middle.

\section{The Librarian's Colleagues}

The colleague relationship is probably the most important relationship in any occupation. Who sets the standards? With whom can one talk freely about the job?

Probably the most satisfying colleague relationship for the college librarian, where he can achieve it, is with the teaching faculty. We have discussed above the obstacles which stand in the way of the librarian in achieving this relationship. It is not usually available to any librarian except the chief, and it is not automatically accorded even to him. Furthermore, the relationship is not a true colleague relationship, because the instructor is also the primary client of the librarian.

There is colleagueship, of course, with other librarians. And, if the college is large enough to have a large library staff, the staff group will be the colleague group, though the head librarian may, as boss, be excluded. If the staff is very small, there is still the possibility of establishing a colleague relationship with other librarians in 
the community. Specialization, however, usually bars effective communication here. The functions and problems are not really comparable.

The true colleagues, of course, are other college librarians. But there are so few of them in any area that communication is difficult. One or two journals and the state and national library conventions provide the only channels.

\section{The College Librarian in the Library WORLD}

Librarians are currently much concerned with the identification and definition of the central body of knowledge and skills which can be called the core of librarianship. They are concerned, first of all, because the library profession is young, self-consciously seeking to establish for itself the attributes which are accepted as the marks of a "profession." A recent workshop report asks:

If no central body of knowledge exists, is there then any library profession at all? Such a question arises out of the assumption that a core of knowledge is an essential characteristic of a true profession. Those who hold this point of view shift the burden of proof to those who oppose the core concept: accept a core, or reject professional status.... The gist of the anticore position is that ... where certain broad areas of subject matter (cataloging, classification, book selection, etc.) seem to be common to all types of library work, the approaches are so different that special orientation is better than any basic introduction upon which so many alterations will have to be imposed. ${ }^{5}$

The definition of the core is a practical problem for the profession insofar as the profession takes on the responsibility for

- The Core of Education for Librarianship, a report of a workshop held under the auspices of the Graduate Library School of the University of Chicago, August I0-I 5, 1953. Edited by Lester Asheim. Chicago, American Library Association, 1954. making formal arrangements to control the recruiting and training of new entrants to the profession. It is a difficult problem, too, as the anti-core position cited above implies.

But beyond practical considerations, the core problem is loaded with prestige factors. For within those "broad areas of subject matter ... which seem to be common" the easily distinguishable common elements are a limited number of cabalistic practices. Their application requires learning and judgment, but as soon as we move into application we move also into specialization and out of the core. If the core is defined in terms of these common techniques and skills, the librarian, as librarian, finds it difficult to maintain his self-esteem. So he tends to add to the core such generalized areas as professional attitudes, liberal arts, understanding of the processes and agencies of communication. At present the curricula of most library schools do, in fact, attempt to provide professional training of this sort. They try to produce a bookman, a scholar, perhaps, who is equipped with some library skills and orientation.

Now how does all this relate to the college librarian? It has been shown that the college librarian has an anomalous status in the college. In his competition with his faculty colleagues, he is hampered by the fact that his own profession is relatively low in social status. And he is further hampered by the fact that the part of his training which is distinctively recognizable as librarianship is unimpressive. Finally, as the statement quoted earlier indicates, if he is in fact a bookman or an educator, he is sometimes assumed to be so not because of, but almost in spite of his library training. One could almost say that the college librarian who identifies himself with the 
library world loses status in the academic world.

\section{The College Librarian's Career}

Obviously the career pattern of the college librarian is affected by these considerations. His training is favorably affected by the difficulty of defining the core. If the common skills and techniques in the core are supplemented by general cultural and "books" courses, he gets, in effect, advanced general education. Since the liberal arts college librarian is a specialist in "generalism," this is all to the good.

Once on the job, however, he faces the problems of advancement and mobility. $\mathrm{He}$ is under natural status pressure, as we have seen, to identify with the academic world rather than the library world. As librarian, his mobility within the institution is blocked. He may, then, move in the direction of acquiring additional administrative or instructional skills and responsibilities, thus moving farther and farther away from the library world. He may resist, or be unable to cope with, the status pressure within the institution and maintain his identification with the library world and his mobility within it. Finally, if he is good enough, he may be able to straddle the fence, using publication and scholarship to maintain prestige both in his college and in the library world.

\section{Conclusion}

The sociology of librarianship has never been systematically studied. The present description of one library specialization is based on purely personal observation of and experience with a very few college libraries. It is intended only to suggest some of the problems and relationships which are provocative of analysis and research. We should like to know, for instance, what is the "librarian" stereotype? Is the "college librarian" stereotype different? What are the various ways in which college librarians have adjusted to the status problems they face? How do they rate with their faculty colleagues? What is their place in the power structure of the college? Do they think of themselves, and are they thought of by others, primarily as administrators, as educators, or as bookmen? Who are their favorite clients? How do they solve the problem of colleagueship? What is their usual career pattern? How many of them are itinerant professionals, advancing by moving from college to college? How many move out of librarianship into other fields? How many move into other library specializations?

As librarianship becomes increasingly concerned with its social role, these questions and many others will need to be answered.

\section{Societas Bibliographica}

Theodore Besterman has established at Geneva the Societas Bibliographica, for the production of important works of reference which cannot be handled on a commercial basis. The first publications to be issued over the imprint of the Societas Bibliographica are a third edition of Mr. Besterman's own World Bibliography of Bibliographies, and a second edition of Alfred Loewenberg's Annals of Opera. The first volume of the new World Bibliography appeared in December 1954; the new Annals will appear in February 1955. The editorial address of the Societas Bibliographica is 25 rue des Délices, Geneva, Switzerland; the business address 8 rue Verdaine, Geneva. 